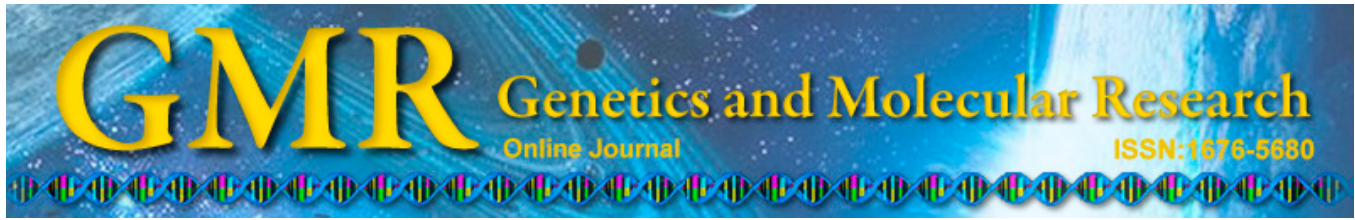

\title{
Morphology and photosynthetic enzyme activity of maize phosphoenolpyruvate carboxylase transgenic rice
}

\author{
W.C. Li ${ }^{1}$, J. Wang', Y.L. Sun ${ }^{1}$, S.D. Ji ${ }^{1}$ and S.W. Guo ${ }^{2}$ \\ ${ }^{1}$ College of Life Sciences, Henan Normal University, Xinxiang, China \\ ${ }^{2}$ Institute of Food Crops, Jiangsu Academy of Agricultural Sciences, Nanjing, \\ China
}

Corresponding author: S.W. Guo

E-mail: guosw123@126.com

Genet. Mol. Res. 14 (4): 15572-15576 (2015)

Received August 15, 2015

Accepted October 24, 2015

Published December 1, 2015

DOI http://dx.doi.org/10.4238/2015.December.1.8

\begin{abstract}
The morphology and photosynthetic enzyme activity were studied in maize phosphoenolpyruvate carboxylase transgenic rice and non-transgenic rice. The results showed that compared with non-transgenic rice, phosphoenolpyruvate carboxylase transgenic rice was taller and had a stronger stalk, wider leaves, and more exuberant root system, with increased photosynthetic enzyme activity and improved yield components. Therefore, given the superiority of this plant type and heterosis, this is a novel breeding strategy for rice for the introduction of $\mathrm{C}_{4}$ photosynthesis genes into high-yielding rice.
\end{abstract}

Key words: Phosphoenolpyruvate carboxylase gene; Rice; Photosynthetic enzyme activity 


\section{INTRODUCTION}

Long-term reduction in photosynthetic efficiency caused by bright light is known as photo inhibition. In most $\mathrm{C}_{3}$ plants, particularly rice, photo inhibition is a common phenomenon because of its strong photorespiration. $\mathrm{C}_{4}$ plants possess the $\mathrm{C}_{4}$ photosynthetic pathway, with a $\mathrm{CO}_{2}$-concentrating mechanism enabling $\mathrm{C}_{4}$ plants to achieve higher photosynthetic capacity and higher water and nitrogen use efficiencies. Thus, the transfer of $\mathrm{C}_{4}$ traits to $\mathrm{C}_{3}$ plants can be used to improve the photosynthetic performance of $\mathrm{C}_{3}$ plants (Matsuoka et al., 2001). Previous studies have attempted to develop $C_{3}$ plants expressing $C_{4}$ traits using conventional hybridization (Brown and Bouton, 1993); however, these attempts have been unsuccessful. Recent progress in the development of molecular biology techniques, particularly the molecular engineering of photosynthetic genes, has resulted in the production of transgenic rice overexpressing phosphoenolpyruvate carboxylase (PEPC) using an agrobacterium transformation system (Agrie et al., 1998; Kums et al., 1999). In this study, the photosynthesis and morphology of the transgenic rice were analyzed and compared, providing a basis for the genetic improvement of rice.

\section{MATERIAL AND METHODS}

\section{Plant materials}

Maize was introduced into new japonica 18 to obtain transgenic rice. These plants were potted in the rice experimental fields of Henan Normal University under natural light conditions.

\section{Extraction of leaf soluble protein and enzyme assays}

First, $2 \mathrm{~g}$ rice leaf was ground in Tris- $\mathrm{HCl}$ buffer in an ice bath; after filtration through 8 layers of gauze, the filtrate was centrifuged for $20 \mathrm{~min}$ in $10,000 \mathrm{~g}$ at $4^{\circ} \mathrm{C}$. The supernatant was the enzyme soluble extract. PEPC activity was assayed using the method described by Gonzalez et al. (1984). The carboxylase activity was assayed as described previously (Guo et al., 1988). For nicotinamide adenine dinucleotide phosphate (NADP)-malate dehydrogenase and ribulosebisphosphate carboxylase, the activity assay was separately performed using the methods described Li et al. (1987) and Kung et al. (1980).

\section{RESULTS}

\section{Morphology}

A series of transgenic rice of various shapes was obtained by introducing PEPC. Compared with japonica 18, PEPC transgenic rice was taller and had a more exuberant root system (Figure 1), wider leaves, and stronger stalks (Figure 2). The panicles per plant, ear length, grain weight, and yield per plant were increased by $30.2,7.5,8.9$, and $32.1 \%$, respectively, compared with the controls. This indicates that changes in shape were closely related to production. 


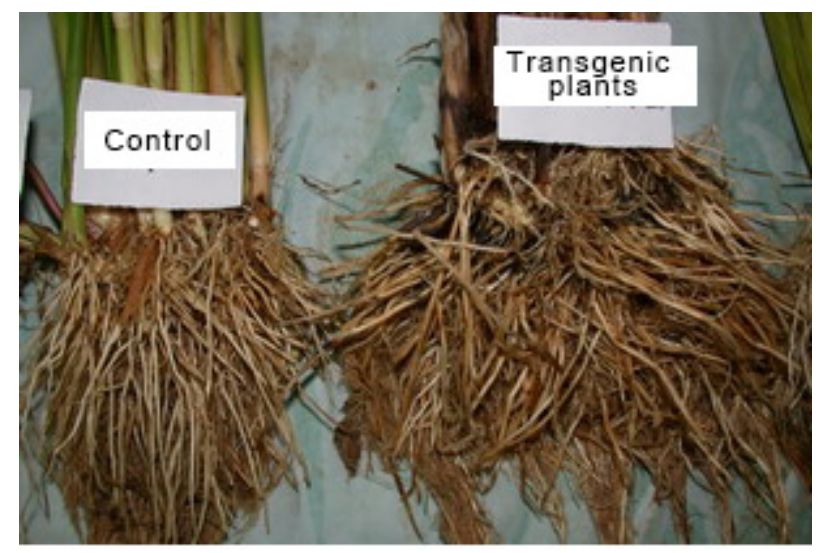

Figure 1. Comparison of root gene transfer and control plant.

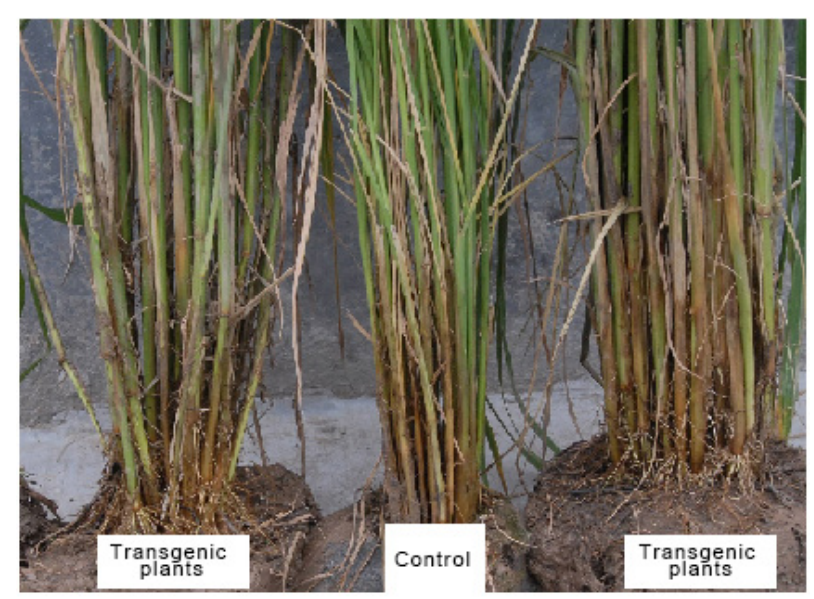

Figure 2. Comparison of stem of transgenic plants and controls.

\section{Photosynthetic enzyme activity}

Under natural light conditions $\left(350 \mu \mathrm{mol} \cdot \mathrm{m}^{-2} \cdot \mathrm{s}^{-1}, 21 \% \mathrm{O}_{2}, 350 \mu \mathrm{L} / \mathrm{L} \mathrm{CO}_{2}, 30^{\circ} \mathrm{C}\right.$, for $3 \mathrm{~h}$ ), the PEPC activity of transgenic rice was significantly higher than in controls, while the activities of CA, NADP-malate dehydrogenase, and ribulosebisphosphate carboxylase were constant (Figure 3A).

Under conditions of photo inhibition $\left(1000 \mu \mathrm{mol} \cdot \mathrm{m}^{-2} \cdot \mathrm{s}^{-1}, 2 \% \mathrm{O}_{2}, 60 \mu \mathrm{L} / \mathrm{L} \mathrm{CO}_{2}, 30^{\circ} \mathrm{C}\right.$, for $3 \mathrm{~h}$ ), compared with the control group, the ribulosebisphosphate carboxylase activity of transgenic rice exceeded 5\% (no significant difference), while the activities of PEPC, CA, and NADP-malate dehydrogenase exceeded 282.3, 23.1, and 25.6\%, respectively (Figure 3B). The activities of all $\mathrm{C}_{4}$ photosynthetic enzymes in transgenic lines increased and exceeded those in the control group following suppression of light. Thus, transformant plants had higher levels of PEPC activity, significantly improving photosynthesis. 


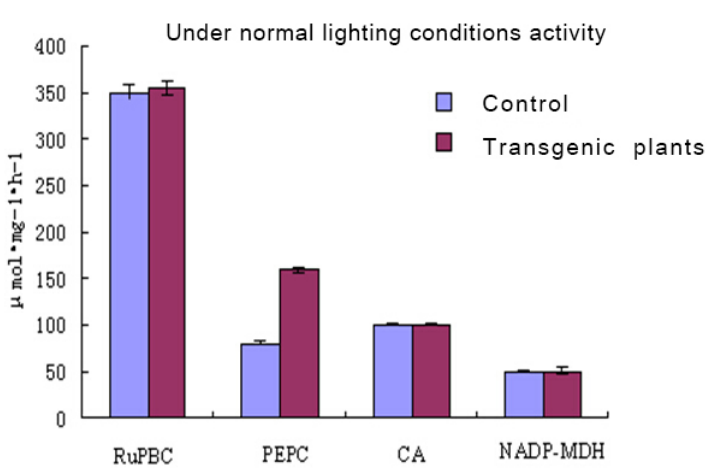

A

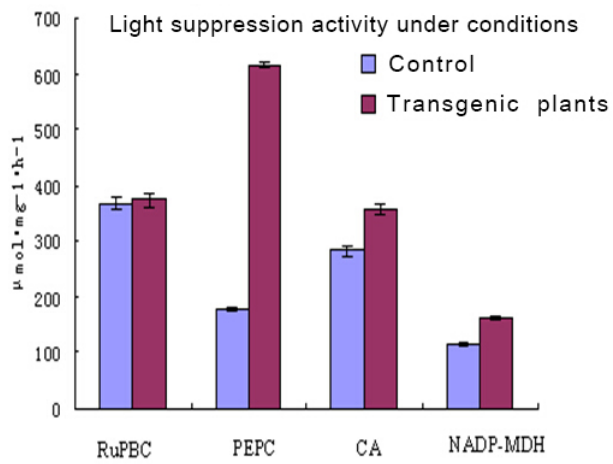

B

Figure 3. Leaves of transgenic lines and control of light synthase activity. A. Under natural light condition; B. under conditions of photo inhibition.

\section{DISCUSSION}

Whether the $\mathrm{C}_{4}$ photosynthetic pathway exists in $\mathrm{C}_{3}$ plants is unclear, as $\mathrm{C}_{4}$ plant leaves possess the Kranz structure, while $\mathrm{C}_{3}$ plants do not. It has been reported that the leaves of $\mathrm{C}_{3}$ crops, such as soybeans (Li et al., 2001), wheat (Hata and Matsuoka, 1987), and rice (Wang et al., 2002), contain $\mathrm{C}_{4}$ photosynthetic enzyme systems. Transforming $\mathrm{C}_{4}$ cycle enzyme genes into $\mathrm{C}_{3}$ crops is considered to be an important method for improving photosynthetic efficiency and crop yield. Chen and Ye (2001) found that the photosynthesis efficiency of spinach leaves was improved when the original products of the photosynthesis (oxaloacetate/malate) were added. This provides a basis for establishing the $\mathrm{C}_{4}$ micro-circulatory system in $\mathrm{C}_{3}$ plants to improve the efficiency of photosynthesis.

Conventional, physiological, and biotechnological breeding are traditionally used in the development of crop breeding (Austin et al., 1984), Contemporary plant physiologist and breeding workers give attention to the high light efficiency physiological breeding, particularly in the study of including $\mathrm{C}_{4}$ photosynthetic capabilities into $\mathrm{C}_{3}$ crops (Kum et al., 1996; Edwards, 1999). To investigate the microcirculation and its physiological function of $\mathrm{C}_{4}$ in rice, the PEPC gene from maize was transformed into the new japonica rice 18. We obtained a series of transgenic lines with increased plant height, improved root development, broadened leaves, and thickened stems. Compared with the control group, in the transgenic lines, both the biological and economic yields were high, and photosynthetic enzyme activity was also greatly enhanced. The result agrees with that of Jiao et al. (2001). Zhou et al. (2001) found that overexpression of PEPC alleviated drought stress on rice. Ding et al. (2012) found that under drought stress, overexpression of PEPC enhanced the highlight tolerance of the rice, which is consistent with our results regarding the transgenic plants' morphological changes in developed root and thickened stem. Changes in the shape of transgenic lines may be the physiological basis of resistance and increase yield in PEPC transgenic rice. Therefore, given the superiority of this plant type and heterosis, this is a novel breeding strategy for rice for the introduction of $\mathrm{C}_{4}$ photosynthesis genes into highyielding rice. 


\title{
ACKNOWLEDGMENTS
}

\author{
Research supported by the National Natural Science Foundation of China (\#1304317).
}

\section{REFERENCES}

Agrie S, Tsuchida H and Kums B (1998). High level expression of $\mathrm{C}_{4}$ enzymes in transgenic rice plant. Kluwer Academic Publishers, Domdrecht.

Austin RB, Ford MA, Morgan CL, Kaminski A, et al. (1984). Genetic Constraints on Photosynthesis and Yield in Wheat. In: Advanced in Photosynthesis Research. Vol. 4. (Sybesma C, ed.). MartinusNijhoff/Dr. W. Junk Publishers, The Hague, 103-110.

Brown RH and Bouton JH (1993). Physiology and genetics of interspecific hybrids between photosynthetic types. Annu. Rev. Plant Physiol. Plant Mol. Biol. 44: 435-456.

Chen GY and Ye JY (2001). Oxaloacetic acid and malic acid of spinach leaves and complete chloroplast photosynthesis. Zhi Wu Sheng Li XueBao 27: 478-482.

Ding ZS, Zhou BY, Sun XF, et al. (2012). Under drought stress PEPC expression ability of rice resistance to strong light. Zио Wи Хиевао 38: 285-292.

Edwards G (1999). Tuning up crop photosynthesis. Nat. Biotechnol. 17: 22-23.

Gonzalez DH, Iglesias AA and Andeo CS (1984). On the regulation of phosphoenolpyruvate carboxylase activity from maize leaves by L-malate. Effect of pH. J. Plant Physiol. 116: 425-434.

Guo ML, Gao YZ and Wang Z (1988). The plant is measured by pH meter carbonic anhydrase activity. Zhi Wu Sheng Li Xue Tong Xun 59-61.

Hata S and Matsuoka M (1987). Immunological studies on pyruvate orthophosphate dikinase in $\mathrm{C}_{3}$ plants. Plant Cell Physiol. 28: 635-641.

Jiao DM, Li X, Huang XQ, et al. (2001). Turn PEPC gene photosynthetic $\mathrm{CO}_{2}$ assimilation and chlorophyll fluorescence characteristics of rice. KeXue Tong Bao 46: 414-418.

Kum SB, Kano-Murakami Y and Matsuoka M (1996). Evolution and expression of $\mathrm{C}_{4}$ photosynthesis genes. Plant Physiol. 111: 949-957.

Kums B, Agarie S, Nomura M, Fukayama H, et al. (1999). High level expression of maize phosphoenolpyruvate carboxylase in transgenic rice plants. Nat. Biotechnol. 17: 76-80.

Kung SD, Chollet R and Marsho TV (1980). Crystallization and assay procedures of tobacco ribulose 1,5-bisphosphate carboxlase-oxygenase. In: Methods in Enzymology (Pietro AS, ed.). Academic Press, New York.

Li B, Chen DL and Shi JN (1987). Sorghum NADP malate dehydrogenase of purification and molecular features. Zhi Wu Sheng Li Yu Fen Zi Sheng Wu XueXueBao 13: 113-121.

Li WH, Lu QT, Hao NB, et al. (2001). C4 cycle way soybean enzyme. Zhi Wu XueBao 43: 805-808.

Matsuoka M, Furbank RT, Fukayama H and Miyao M (2001). Molecular engineering of $\mathrm{C}_{4}$ photosynthesis. Annu. Rev. Plant Physiol. Plant Mol. Biol. 52: 297-314.

Wang Q, Lu CM, Zhang QD, et al. (2002). The super-high-yield hybrid rice combination, photo synthesis, the photo inhibition and C4 pathway enzyme properties. ZhongGuoKeXue 45: 468-476.

Zhou BY, Ding ZS and Zhao M (2011). PEPC through expression can alleviate drought stress on rice photosynthetic inhibition. Zuо Wи ХиеBao 37: 112-118. 